\title{
Kalsiumantagonister ved høyt blodtrykk
}

\author{
Det finnes et stort utvalg av blodtrykksmedisiner tilhørende mange \\ medikamentgrupper, og det kommer stadig resultater fra nye kliniske \\ studier. Dette gjelder også for kalsiumantagonister, som ble etablert \\ som blodtrykksmedikamenter allerede i 1970-årene. Hvilken plass har \\ de i dagens blodtrykksbehandling?
}

Se også kunnskapsprøve på www.tidsskriftet.no/quiz

Kalsiumantagonister senker blodtrykket effektivt, og i kontrollerte kliniske forsøk er det vist at de forebygger kardiovaskulære hendelser. De fleste vurderinger av antihypertensiv behandling konkluderer med at nytten i første rekke er knyttet til blodtrykksreduksjonen per se og i det vesentlige uavhengig av hvilket medikament som benyttes (1).

\section{Materiale og metode}

Artikkelen er basert på egen litteraturbase og ikke-systematiske søk i PubMed med et skjønnsomt utvalg artikler basert på forfatternes egen erfaring på området.

\section{Virkningsmekanismer}

Ved essensiell hypertensjon er den perifere karmotstanden forhøyet på grunn av økt tonus i arteriolenes glatte muskelceller. Tonusøkningen er knyttet til høy intracellulær kalsiumionekonsentrasjon.

Kalsiumantagonistene hemmer influks av kalsiumioner i glatte muskelceller og senker dermed den perifere karmotstanden (fig 1). Dette er virkningsmekanismen for dihydropyridinderivatene (amlodipin, felodipin, isradipin, nifedipin, lerkanidipin). Verapamil (fenylalkylamin) og diltiazem (benzotiazepin) har i tillegg en negativ inotrop virkning på myokard, noe som også bidrar til blodtrykksreduksjonen. Alle de nevnte kalsiumantagonistene er registrert i Norge.

\section{Kontrollerte kliniske studier}

\section{Kalsiumantagonister mot placebo}

Nytten av kalsiumantagonister er dokumentert i flere kliniske studier. I en metaanalyse som inkluderte vel 7000 pasienter ble det funnet statistisk signifikante reduksjoner i endepunktene slag (38\%), koronarsykdom $(22 \%)$, større kardiovaskulære hendelser (18\%) og kardiovaskulær død (22\%) (2). Det var en ikke-signifikant økning i hyppigheten av hjertesvikt $(21 \%, p=0,17)$ og en ikke-signifikant reduksjon i totaldødelighet $(11 \%, p=0,99)$.

\section{Kalsiumantagonister}

\section{mot andre antihypertensiver}

Dihydropyridinderivater, diltiazem og verapamil er i kontrollerte kliniske studier og i metaanalyser blitt sammenliknet med diuretika/ $\beta$-blokkere, ACE-hemmere og andre antihypertensiver (2-6). I disse sammenlikningene var det $\mathrm{i}$ noen studier en tendens $\mathrm{i}$ retning av færre slag hos dem som ble behandlet med kalsiumantagonister. For andre kardiovaskulære endepunkter varierte resultatene. I de fleste studiene ble det funnet flere tilfeller av hjertesvikt (2-5) og i noen studier også flere koronare hendelser $(3,5)$ enn i sammenlikningsgruppene.

En mye omtalt studie nevnes spesielt fordi resultatene ofte er blitt feiltolket. I ASCOTBPLA-studien (Anglo-Scandinavian Cardiac Outcomes Trial Blood Pressure Lowering Arm) $(n=19257)$ var basisbehandlingen enten amlodipin eller atenolol (7). Etter 5,5 år var risikoen for det primære endepunktet (ikke-fatalt hjerteinfarkt inkludert stumt infarkt og fatal hjertesykdom) i amlodipingruppen ikke-signifikant redusert med 10\%. Derimot var det, sammenliknet med atenolol, statistisk signifikant reduksjon når det gjaldt flere sekundære kardiovaskulære endepunkter. Men etter justering for større blodtrykksreduksjon ved amlodipinbasert behandling, samt for biokjemiske og kliniske variabler, var det ikke lenger statistisk signifikante forskjeller mellom de to behandlingsgruppene (8).

I den nylig publiserte ACCOMPLISHstudien, der en fast kombinasjon av benazepril (ACE-hemmer) og amlodipin ble sammenliknet med benazepril og hydroklortiazid (9), kom den førstnevnte behandlingen best ut. Det primære endepunktet (kombinasjon av kardiovaskulær hendelser og kardiovaskulær død) ble redusert med $20 \%$. Forekomsten av fatalt og ikkefatalt hjerteinfarkt var $22 \%$ lavere, for det sekundære endepunktet hospitalisering for hjertesvikt var den lik i begge gruppene $(1,7 \%)$.

\section{Bivirkninger}

Kalsiumantagonister, særlig dihydropyridinderivater, kan gi ankelødemer, hodepine og «flushing». For øvrig gir preparatene få subjektive plager. Verapamil og diltiazem har i større doser en negativ inotrop effekt, og de kan også forårsake atrioventrikulært blokk. Kalsiumantagonistene har ikke ugunstige metabolske effekter.

\section{Medikamentvalg/ kombinasjonsbehandling}

Kalsiumantagonister er, på linje med andre antihypertensiver, et alternativ ved oppstart og vedlikehold av hypertensjonsbehandling. Dog er det indisier på at de ulike antihypertensivene kan ha særlige fortrinn ved spesielle sykdomstilstander. Kalsiumantagonistene peker seg ikke ut som typiske førstelinjemedikamenter. Årsaken er blant annet at noen forskere har vært kritiske til bruk av kalsiumantagonister som førstevalg ved hypertensjon fordi de sammenliknet med andre antihypertensiver er dårligere til å forebygge hjertesvikt. I tillegg er det usikkert hvor effektivt de forebygger koronare hendelser (3). I de europeiske hypertensjonsretningslinjene fra 2007 er det gitt en oversikt over foretrukket legemiddel ved ulike tilstander (tab 1) (10).

Ofte er det behov for mer enn ett medikament for å nå blodtrykksmålet, og hos pasienter med høy risiko kan behandlingen starte med to medikamenter. Kalsiumantagonister er velegnet for å kombineres med tiazider, ACEhemmere og AII-reseptorblokkere. Dihydropyridinderivatene, men ikke verapamil og diltiazem, kan også kombineres med $\beta$-blokkere.

I de senere år er det blitt vanligere å kombinere ulike substanser i én tablett. Mest vanlig er kombinasjonstabletter som inneholder et tiazid (hydroklortiazid) og enten en ACE-hemmer eller en AII-reseptorblokker. I mange land har kombinasjonstabletter vært vanligere enn i Norge. Kombinasjonen av

\section{Hovedbudskap}

- Kalsiumantagonistene reduserer den perifere karmotstanden og har en sikker antihypertensiv effekt

- Kalsiumantagonister egner seg utmerket i kombinasjon med de fleste andre antihypertensiver

- Medikamentene kan utløse hjertesvikt 

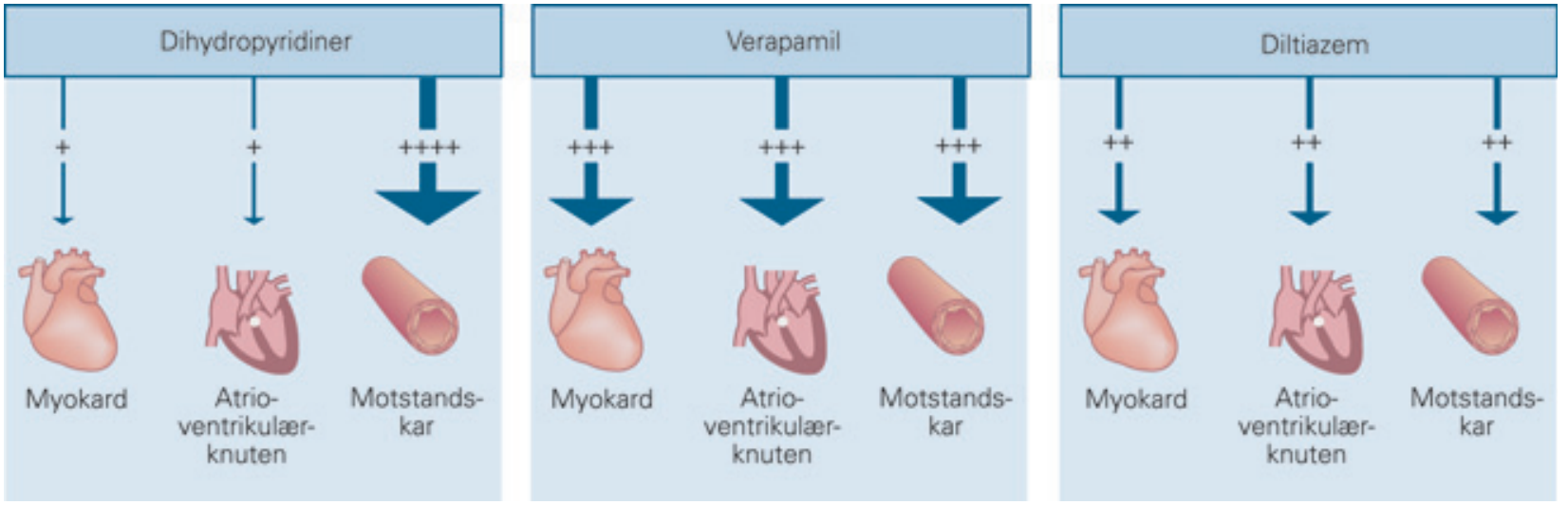

Figur 1 Hemmende effekt av kalsiumantagonister på myokard, atrioventrikulærknute og motstandskar

amlodipin og valsartan (AII-reseptorblokker) har allerede markedsføringstillatelse her i landet, og det er grunn til å tro at flere kombinasjonstabletter etter hvert vil bli lansert.

\section{Konklusjon}

Det er noe divergerende oppfatninger om hvordan de ulike antihypertensivene skal brukes i klinisk praksis. De europeiske retningslinjene anbefaler stor frihet $\mathrm{i}$ valg av førstelinjemedikament (10), mens de sist publiserte amerikanske retningslinjene angir tiazider som førstevalg (11). Nye amerikanske retningslinjer er ventet i 2010. Kalsiumantagonistene har gunstig hemodynamisk profil. Etter vår vurdering kan disse i spesielle situasjoner være egnet enten som førstevalg eller de kan legges til når målblodtrykket ikke nås med andre medikamenter. Kostnadshensyn gjør at myndighetene siden 2004 har bestemt at tiazider skal være førstevalget hos pasienter med ukomplisert hypertensjon i Norge.

Hos pasienter med hjertesvikt skal diltiazem og verapamil ikke brukes, og forsiktighet må også utvises ved bruk av dihydropyridiner - ingen bruk ved ikke-kompensert hjertesvikt.

\section{Knud Landmark}

k.h.landmark@medisin.uio.no

Åsmund Reikvam

Institutt for farmakoterapi

Fakultetsdivisjonen Rikshospitalet

Universitetet i Oslo

Postboks 1065 Blindern

0316 Oslo

Oppgitte interessekonflikter: Knud Landmark har mottatt honorar og/eller reisestøtte fra Pharmacia/Pfizer, SolvayPharma og Leo Pharma, Åsmund Reikvam har fått honorar for foredrag, møteledelse og rådgivning og/eller reisestøtte fra AstraZeneca, MSD, Novartis og NycomedPharma.

\section{Litteratur}

Blood Pressure Lowering Treatment Trialist's Collaboration. Effects of different regimens to lower blood pressure on major cardiovascular events in older and younger adults: meta-analysis of randomised trials. BMJ 2008; 336: 1121-3.

2. Blood Pressure Lowering Treatment Trialists' Collaboration. Effects of different blood-pressurelowering regimens on major cardiovascular events: results of propectively-designed overviews of randomised trials. Lancet 2003; 362: 1527-35.

3. Pahor M. Psaty BM, Alderman MH et al. Health outcomes associated with calcium antagonists compared with other first-line antihypertensive therapies: a meta-analysis of randomised controlled trials. Lancet 2000; 356: 1949-54.

4. Psaty BM, Lumley T, Furberg CD et al. Health outcomes associated with various antihypertensive therapies used as first-line agents. A network meta-analysis. JAMA 2003; 289: 2534-44.

5. www.kunnskapssenteret.no/Publikasjoner/ 4786.cms (15.10.2009).

6. The ALLHAT Officers and Coordinators for the ALLHAT Collaborative Research Group. Major out comes in high-risk hypertensive patients randomized to angiotensin-converting enzyme inhibitor or calcium channel blocker vs diuretic. The antihypertensive and lipid-lowering treatment to prevent heart attack trial (ALLHAT). JAMA 2002; 288: $2981-97$

7. Dahlöf B, Sever PS, Poulter NR et al, for the ASCOT investigators. Prevention of cardiovascular events with an antihypertensive regimen of amlodipine adding perindopril as required versus atenolol adding bendroflumethiazide as required, in

the Anglo-Scandinavian Cardiac Outcomes TrialBlood Pressure Lowering Arm (ASCOT-BPLA): a multicentre randomised controlled trial. Lancet 2005; 366: 895-906.

8. Poulter NR. Wedel H. Dahlöf B et al, for the ASCOT investigators. Role of blood pressure and other variables in the differential cardiovascular event rates noted in the Anglo-Scandinavian Cardiac Outcomes Trial-Blood Pressure Lowering Arm (ASCOT-BPLA). Lancet 2005: 366: 907-13.

9. Jamerson K, Weber MA, Bakris GL et al. Benazepril plus amlodipine or hydrochlorothiazide for hypertension in high risk patients. N Engl J Med 2008: 359: 2417-28

10. Mancia G, De Backer G, Dominiczak A et al. 2007 Guidelines for the Management of Arterial Hypertension. The Task Force for the Management of Arterial Hypertension of the European Society of Hypertension (ESH) and of the European Society of Cardiology (ESC). J Hypertens 2007; 25: 1105-87.

11. Chobanian AV, Bakris GL, Black HR et al. The Seventh Report of the Joint National Committee on Prevention, Detection, Evaluation, and Treatment of High Blood Pressure. The JNC 7 Report. JAMA 2003; 289: $2560-72$

Manuskriptet ble mottatt 27.2. 2009 og godkjent 15. 10. 2009. Medisinsk redaktør Anne Kveim Lie.

Tabell 1 Foretrukne legemidler ved antihypertensiv behandling. Oversatt og gjengitt etter tillatelse fra Journal of Hypertension (10)

\section{Kliniske hendelser \\ Tidligere slag \\ Tidligere hjerteinfarkt \\ Angina pectoris \\ Hjertesvikt}

\section{Atrieflimmer}

Paroksystisk

Permanent

\section{Perifer arteriesykdom}

\section{Andre tilstander}

Isolert systolisk hypertensjon (eldre)

Metabolsk syndrom

Diabetes mellitus

Graviditet

\section{Legemiddel}

Alle antihypertensiver

$\beta$-blokkere, ACE-hemmere, All-reseptorblokkere

$\beta$-blokkere, kalsiumantagonister

Diuretika, $\beta$-blokkere, ACE-hemmere, All-reseptorblokkere, aldosteronantagonister

All-reseptorantagonister, ACE-hemmere

$\beta$-blokkere, ikke-dihydropyridin-kalsiumantagonister Kalsiumantagonister

Diuretika, kalsiumantagonister

ACE-hemmere, All-reseptorblokkere, kalsiumantagonister

ACE-hemmere, All-reseptorblokkere

Kalsiumantagonister, metyldopa, $\beta$-blokkere, diuretika 